\title{
Reforming labor markets: reflections of an economist who (unexpectedly) became the Italian Minister of Labor
}

\author{
Elsa Fornero \\ "It's easy, impossible, tough going, worth a shot". \\ Wislawa Szymborska, "Poems, New and Collected, 1957-1997", Houghton Mifflin Harcourt, Boston, 2000.
}

Correspondence: elsa.fornero@unito.it University of Turin and CeRP-Collegio Carlo Alberto, Turin, Italy

\begin{abstract}
Technocratic Minister of Labor in an economic emergency, with the assignment to devise two key reforms (pension system and labor market): a unique, though hard experience for an academic, confirming the gap between economic research and real life. This paper gives an account of the Italian labor market reform, an attempt to reconcile economic logic, social expectations, requests from European institutions and financial constraints. This reform survived difficult social dialogue and long Parliamentary debates and had severe communication problems; resulting however in a comprehensive law aiming at inclusion, dynamism and higher productivity and representing a chance of better prospects for the young.
\end{abstract}

JEL code: $J 080$

Keywords: Labor reform; Labor law; Italy

Contents: Autumn 2011: Italy on the edge p 2-Technocrats in power: a wealth tax and the pension reform in the "Rescue Italy" plan p 3-Tackling structural labor problems: the search for a good equilibrium among conflicting stakeholders p 6-A comprehensive reform resting on five pillars p 10-Opposition, latent contradictions and political double standards $\mathrm{p}$ 16-Dynamic inconsistencies: short term effects and long term perspectives p 20-Conclusion: Alice through the looking glass p 23-Additional file 1: A statistical comparison of the Italian and European labor markets

\section{Autumn 2011: Italy on the edge}

On May 29th, 2013, the European Commission decided to end the "Infraction procedure for excessive deficit” opened against Italy in 2009. As a member of Italy's former "technocratic" government, responsible for drafting two major laws-the Pension and Labor Market reforms-I could finally draw a sigh of relief. Brussels' decision showed that the sacrifices the government had to impose on Italians in order to realize fiscal consolidation were starting to pay off.

These as well as other reforms were the result of a sharp decline of the Italian sovereign debt credibility in Summer 2011, which brought the Country to the verge of a financial crisis, with likely devastating consequences also for Europe and the Euro ${ }^{1}$. Italy 
had (and still has) to refinance, on average, one billion Euros a day of its huge public debt (over 130 per cent of GDP) and its well-tested system for doing so had come under massive attack. Financial operators had turned their backs on debt auctions and the few who took part were demanding exorbitant interest rates, so that the spread of the interest rate of Italian 10-year bonds over their German counterparts rose to over 550 basis points. It is therefore not rhetorical to say that financial breakdown was round the corner and that the possibility of unhonored sovereign debt was very real; even pensions and civil service salaries were at risk. Central and local administrations were already unable to pay suppliers, whose claims exceeded 70 billion Euros. Many observers were pointing to the risk that Italy might become the "new Greece" (Gammelin and Bachstein 2011 and Brummer 2011), with much worse consequences on both economic and social stability inside the country and in the whole Euro area.

The worsening of the financial situation was, however, only one side of the coin. The other was the structural weakness that has been afflicting the country for about twenty years: growth rates have been significantly lower than elsewhere in Europe and productivity has been either stagnant or declining. Industrial decline has slowly reduced Europe's once most buoyant economy to a shadow of its former self. Italy had cut its R\&D expenditure, got out of high productivity sectors like electronics, chemicals and drugs, and concentrated instead on labor intensive fashion-oriented "made in Italy" products, where it has been encountering increasingly stiff competition from developing countries.

Politics was at a stalemate. The government first had refused to recognize the gravity of the situation and persisted in making unrealistic promises. In August 2011, however, it yielded to international pressure and pledged to introduce wide-ranging changes (prominent among them pension and labor market reforms), as urged by the ECB in a letter of August $5^{\text {th }}$.

It however could not survive the ensuing confusion among its own parliamentary supporters, who disliked to take responsibility for unpopular restrictive measures. The government resigned on November the $12^{\text {th }}$ in a situation of political chaos and the President of the Republic appointed Professor Mario Monti, a former member of the EU commission, as head of a "technocratic" government, composed of experts drawn from civil society and with no political affiliation. The new government received a vote of confidence (Nov 16th, 2011) by a "strange" Parliamentary majority, composed of the two political parties (centre-left and centre-right) who had been acrimoniously fighting each other for the past twenty years.

\section{Technocrats in power: a wealth tax and the pension reform in the "Rescue Italy" package}

The new Government had no time to waste, and little time to fine-tune the first emergency measures. On November 16th the plea: "FATE PRESTO!" (Act immediately) was splashed in capital letters on the front page of Il Sole 24Ore, Italy's economic daily, reflecting a widely shared sense of urgency. The two measures that were to be the core of the first government bill (the so-called "Rescue Italy" decree) were a wealth tax and the pension reform. The first was limited to property, as Italy lacks a reliable public register of households' financial assets ${ }^{2}$. Moreover, these are largely represented by Italian sovereign bonds whose taxation would have more or less immediate repercussions on interest rates.

As minister of Labor, I was asked by President Monti to prepare an immediate restructuring of Italy's pension system, one of the former government's Summer promises 
to the ECB, not honored before its political collapse. I had studied savings and pensions for more than 20 years; CeRP, the research Center I set up in 1999 and directed since, had conducted detailed research on the structure, growth and trends of Italian pension debt. I was now given the task of reshaping the Italian pension system in less than twenty days! The first lesson I learnt is the existence of a huge gap between analyzing a problem as a researcher and having to make, as a minister, decisions in an emergency, on matters bound to have a very strong impact on my fellow-citizens' life perspectives and plans.

The reform had to stand up to the challenge, and thus not only to be very severe and immediately effective, but also to appear credible to financial markets. It had to cancel distortions still embedded in the system after twenty years of reasonable but exasperatingly slow piecemeal reforms ${ }^{3}$ and provide for demographic transition while reducing the burden on the young and future generations. Due to the financial emergency, there was little time for social dialogue, parliamentary debate and the transition period that is customary in pension reforms. The reform was submitted to Parliament as a Government decree (and therefore approved with a vote of confidence) and was not preliminarily discussed with the social partners. This procedure, entirely due to the urgency imposed by the crisis, created a wound in the relationships with the trade unions for which the government paid a price in the subsequent labor market reform.

The reform did not introduce structural changes in the pension design-essentially a "Notional Defined Contribution (NDC) system"-but had to be quite radical in its application. It extended to all workers (including MPs), as of January $1^{\text {st }} 2012$, the contribution-based method of calculating benefits; it raised the statutory retirement ages and profoundly restructured the so-called seniority pensions, awarded, almost irrespective of age, on the basis of years of work ${ }^{4}$; it aligned, as of 2018, the retirement ages of women to those of men; it indexed all retirement requisites to changes in life expectancy; it froze the indexation of pensions to prices for two years, excluding only pensions up to 1400 Euros per month; it established a "solidarity contribution" on very high pensions ${ }^{5}$.

As a result, according to an international evaluation (OECD 2013), the Italian pension system is now financially sustainable, although the extension of working life requires additional measures to enhance the demand for older workers. Most Italian families had to revise lifetime strategies in order to take account of the new, harsher situation. It is a tribute to the Italian people that, although there were protests and vicious personal attacks against the Minister ${ }^{6}$, the majority of citizens realized that these sacrifices were necessary to clean up the country's financial mess and there were no general strikes and no major opposition, either in Parliament or in the streets.

The ensuing debate, however, almost disregarded what was perhaps the major achievement of the reform: a significant re-balancing, in favor of the young, of generational relationships. Indeed the reform came after twenty years of pensions restructuring that, for political reasons, had made the young pay a high price to the advantage of current and elderly generations, in terms of a frustratingly slow transition towards the new regime. The reform not only reduced the implicit pension debt $^{7}$ but also challenged the "lump of labor fallacy", an undeclared basis of past pension legislation and still a frequent claim in public debate, which accused the reform of reducing the number of jobs available to the young by keeping older workers longer at work. 
Generational fairness (also a feature of the subsequent labor market reform) was much less commented upon, than the marked reduction of the spread that followed the approval of the "Rescue Italy" decree. Taking the long view, however, the former was possibly much more important. The inability to clearly convey this message of a structural change in both the pension and the labor market reforms remains for me a cause for regret and was certainly one of the shortcomings of government action.

\section{Tackling structural labor problems: the search for a "good" equilibrium among conflicting stakeholders}

i) The starting point

In spite of having being subjected to various reforms in the past two decades, meant to reduce rigidities, smooth frictions and overcome segmentation and ideological barriers, the labor market was still plagued, in 2011, by structural shortcomings, distortions and flaws which the economic crisis had severely worsened. Academic research as well as the analyses of international institutions ${ }^{8}$ has provided a stylized picture which unambiguously pointed to a rather inefficient market, sharply segmented along the lines of cohorts, gender and geographical area. Shortcomings, as described in the Additional file 1, were (and still are) mainly structural, and not just the result of the crisis.

Market dualism, i.e. sharp separation between protected groups (mainly men, over forty, in manufacturing and government jobs) and marginalized or excluded ones (the young, women and older workers-see Additional file 1: Figure S1, S2) has been caused by successive layers of legislation, which created rigidities, on one side, and "bad" flexibility, i.e. precariousness (Additional file 1: Table S1, S2, S3), on the other. Traditionally low participation rates, particularly among women (Additional file 1: Figure S4) and older workers, have been largely determined by lack of care services, often compelling women to choose between work and family, and by early retirement provisions, motivated by restructuring of firms and often conceived, for women, as an ex post compensating factor for their disadvantages in the labor market. An unwarranted separation between school and work has been encouraged by ideological prejudice, causing both insufficient vocational training and lack of adult education (Additional file 1: Table S4, S5, S6).

Selective and discretionary social protection schemes, with prevalence of passive policies (Additional file 1: Table S7) and poor or absent Active Labor Market Policies (ALMP) have been stimulated by decentralization of employment services to Regions, characterized by widely differing efficiency standards.

Finally, a comparatively high fiscal wedge weakened firms' competitiveness (Additional file 1: Table S8).

While present across the entire country, these inadequacies were (and still are) particularly acute in the Southern Italy.

ii) Setting the objectives

With this picture in mind, the government first set the final objectives of the reform, which were identified as promoting inclusiveness and dynamism in the labor market. The task was thus to design an institutional framework capable of guiding the evolution of the market along these lines. 
We did not express the objectives in pre-determined figures, to be attained within a strictly defined time frame. There was little foundation for this kind of precision, which could have been interpreted as yet another political catchword. Instead, we tried to indicate that the reform should stimulate changes in behavior, conducive to better labor relationships and performance.

The attempt to realize an inclusive labor market implied a shift in policy emphasis from jobs to workers and, in particular, from protecting jobs to protecting workers in the market place along four major lines: $i$ by enhancing their employability through apprenticeship schemes, re-training and life-long learning programs, certification of competences; $i i$ by promoting more effective matching tools and quality employment services; iii by establishing a more extensive safety net to substitute for highly selective social protection schemes and $i v$ by organizing reliable active policies.

The attempt to realize a dynamic labor market implied a market with reduced individual dismissal rigidities and shortened school-to-work and job-to-job transitions, again to be realized by more effective active policies, a better coordination between state and regional interventions and between public and private providers of employment services.

The philosophy behind these changes, long advocated by international institutions like the EU, the OECD and the IMF, is clearly in the realm of flexicurity: inclusion and dynamism are the counterpart of "good" labor flexibility and should promote, at least in the medium run, an increase in labor productivity and job opportunities.

\section{iii) Were there feasible alternatives?}

A first option would have been a much harsher modification of the various kinds of contracts, possibly to be substituted by a "single open-ended contract" providing little or no safeguards in the initial phase and then increasing protection throughout the working life, according to the proposal by Boeri et al ${ }^{9}$. While trade unions pressed for the reduction of the number of contracts, they strongly ostracized the "single contract" for creating yet another vehicle by which market segmentation between new entrants and workers already in force would have been enhanced, and yet again to the disadvantage of the young.

A second option could have been represented by a sweeping deregulation of the labor market, through additional deregulation of both temporary and independent work and a more drastic cutback of restrictions on individual dismissals (De Nicola 2012). However sensible this could appear from an economic point of view (and I have doubts that a labor market freed from binding norms would be a rational choice, not to mention the social costs), it would not have been viable politically, given the opposition by at least one of the trade unions (CGIL, the most representative one) and by the party closest to it (the Democratic Party). In any case, it would not have been the choice of this Minister, convinced as I am that encouraging a reduction of labor costs through a progressive impoverishment of labor relationships would have resulted mainly, if not solely, in an increase in casual and precarious jobs. It could have saved some jobs in the short run, but it would have resulted in further productivity decline. Indeed, it is exactly by improving the quality of labor and by investing in human (as well as in physical capital) that productivity and competitiveness can be increased. 
iv) Immediate problems

A serious communication difficulty arose almost at once. Both the media and public opinion assumed that the reform would immediately increase the number of jobs, by providing either a direct support to the demand for labor, through a reduction of the "fiscal wedge" and thus of taxes and/or social contributions, or an indirect one through some fiscal stimulus to aggregate demand. Budget constraints, however, allowed neither of these measures, as the reform had to be implemented at no additional cost for public finance, a provision that obviously severely limited its possibility of having an immediate impact on demand.

It is also important to emphasize (in response to the complaints of various critics about the long course along which the reform was set, particularly since Spain had very swiftly approved a much more radical reform) that our path implied both social dialogue and a thorough parliamentary debate. Indeed, while the pension reform had been implemented through a government decree, for the labor market reform the vehicle had to be (as explicitly requested by the President of the Republic, the custodian and guarantor of the Constitution) a "design law", subject to a more democratic but also lengthier path, with the inevitable trade-off between the need to compromise and the risk of having the reform rejected by Parliament. I think it is fair to remind this to those critics who based their judgments on the adherence of the reform to models, without considering that, in a democracy and in non-emergency conditions, a law provision is inevitably the result of collective action and can hardly be intellectually "pure" (assuming that such "pure" reforms would do good to society).

Finally, the timing of the reform (which depended on previous commitments) was adverse: trying to reduce abuses and to promote stability in a period of job scarcity could seem a bizarre and self-defeating policy. However, a technocratic government does not choose the timing of reforms, indeed, the opposite is true: it is called to introduce reforms exactly when they are most needed and the political parties cannot or will not do the job. What a technocratic government is supposed to do is to search for a good equilibrium among the stakeholders' conflicting interests as well as between short and medium term objectives, which is exactly what we tried to achieve.

\section{A comprehensive reform resting on five pillars}

The government attempted to create a "good" institutional environment, i.e. institutions and procedures acceptable to both workers and employers whose cooperation would be indispensable for success. It further sought to establish "good" rules, i.e. regulations that both workers and employers could consider in their own interest, or in the interest of their children, and translate into consistent behavior. All this required a thorough, large-scale reform working on the different shortcomings of the labor market. The benchmark was the socalled Hartz concept or Hartz reform, named after Peter Hartz, head of a commission whose recommendations over the years, in particular in 2003-05, shaped the German labor market reform (Tompson 2009 and Zimmermann 2013).

The Italian reform rests on five pillars: flexibility in labor market entry; flexibility in labor market exit; social protection schemes; employment services and activation policies; follow up, monitoring and evaluation of the reform. 
i) First pillar

With regard to labor market entry, the reform reduced the large number of existing types of labor contracts with the twofold objective of preserving flexibility and of limiting its improper use, conducive to badly paid, precarious and intermittent jobs as well as to unfair competition both among workers and among firms. Nonstandard contracts concerning the so-called "atypical jobs", and involving both dependent workers (fixed term and part time labor contracts) and apparently independent ones (project-related jobs, self-employed workers with only one client, "associated" workers and interns) have been streamlined and revised with the aim of reducing the ever expanding situations in which the worker is formally autonomous, although he/she is actually an employee.

Fixed term contracts, very popular among employers after liberalization (Sacchi 2013) have been on the one hand further liberalized by exempting employers from having to justify the temporary nature (up to one year ${ }^{10}$ ) of the first contract-or mission, when provided by an agency. On the other hand, they have been made more costly than the standard open-ended contract by levying an extra payroll tax of 1.4 per cent. This is a way to internalize part of the costs that temporary contracts impose on both the worker, who is more likely to become unemployed, and society, which is under the moral obligation to provide both unemployment benefits and support in the search for a new job. In case the contract is transformed into a permanent one, the equivalent of six months' extra contribution is given back to the firm ${ }^{11}$.

According to a widespread criticism the reform is against temporary jobs: they are indeed welcome when they reflect the employer's flexibility needs in order to accommodate organizational or productive requirements. It is however strongly reaffirmed that they cannot be a way to systematically transfer business risks from employers to employees.

Other restrictions were introduced regarding agency workers, whose numbers had shown an anomalous, rapid increase in previous years, clearly a substitute for more protected contracts; and to so-called "associazioni in partecipazione", a contract under which workers are "associated" to the firm, providing human instead of financial capital, and receive a profit related compensation, although their work is entirely similar to that of normal employees. For more disadvantaged unemployed people (older workers displaced by industrial restructuring and women in economically depressed areas) a bonus has been provided for the employer whatever the contract, a substitute for a specific, subsidized contract.

In the permanent contract, apprenticeship is identified and strongly supported as the main entry path into the labor market, with the aim of fostering, through investment in education and vocational training, more skilled and productive workers and more stable employment relationships. On the one hand, the allowed ratio of apprentices to specialized workers has been increased (from 1 to 1 to 3 to 2 ); on the other, given that the contract is highly subsidized in terms of social contributions $^{12}$, an average stabilization rate of 30 per cent up to 2015, and 50 per cent onwards, in the three preceding years is required in order to hire new apprentices.

ii) Second pillar

The counterpart of the effort to make the entry into the labor market less haphazard is provided by the endeavor to reduce exit rigidities. The reform 
reaffirmed the open-ended contract as the "dominant one" and made it less rigid. By modifying long standing and highly symbolic aspects of individual dismissal rules and procedures, established in the "Statute of Workers' Rights", the reform aligned Italy to European legal standards. More specifically, the provisions of article 18 of the Statute-which applies to firms with more than 15 employees or more than 60 in case the firm has more than one plant-are relevant for those judicial cases in which a court has declared the dismissal illegitimate, consequently deciding upon the worker's reinstatement even after various years since dismissal, with uncertain but possibly very high costs for the firm.

It was a routine, not unfounded, complaint by employers that article 18 made individual firing of workers almost impossible and that this was one of the motives for lack of (especially foreign) investments in Italy (Procedures for collective dismissals start from five workers and are activated through negotiations with the trade unions.). On the other hand, article 18 was considered by workers and trade unions an inalienable right, not even subject to a discussion.

The alteration of this article therefore involved much more than mere economic efficiency considerations. Ex ante, this was perhaps the single issue on which the social partners and the political parties were most radically divided. Ex post, changes are, naturally enough, a compromise, but this does not lessen their innovative content when all political and social constraints are taken into due consideration.

The revision is extensive, with the aim of promoting conciliation and discouraging lawsuits, reducing their length (currently up to 6-7 years for the three levels of judgment), limiting the uncertainty about the costs of firing for firms, without restricting workers' fundament rights. In order to achieve these goals, first, a preliminary conciliation procedure has been made compulsory and, second, different sanctions for illegitimate dismissals have been substituted for former unified sanctions, which typically were identified in the worker's reinstatement. On the one hand, discriminatory dismissals (on the ground of race, gender or sexual orientation etc.) continue obviously to be prohibited and thus become null after a sentence has been delivered, so that the dismissal is regarded as if it had never occurred. On the other hand, the reinstatement of workers illegitimately dismissed for economic and disciplinary motives has been restricted to cases where the court recognizes the manifest nonexistence of the motive. In all other cases, it is replaced by a monetary compensation, ranging from 12 to 24 months of salary, depending on the employee's length of service and other criteria.

The time for a dismissed employee to sue the employer has been reduced from 330 to 240 days and a "fast" judicial track for lawsuits has been introduced.

Finally, two further provisions were introduced: a) an additional contribution for dismissals to be paid by the employer, in order to make more transparent their social cost to both the worker and society and b) a procedure to fight the practice of fake resignation concealing dismissals (allegedly widespread and mostly used against women ${ }^{13}$ and immigrant workers).

A comprehensive view of the first two pillars shows the underlying effort to hinder market dualism and to enhance productivity mechanisms: entrance in the labor markets had to be reinforced while the exit mechanisms had to be made less prohibitive. 
iii) Third pillar

Social protection schemes (i.e. passive labor policies) have been substantially revised and, according to the "rights and duties" principle, steps have been taken towards universality and pro-active behavior. Whereas past Italian legislation was mainly focused on employment protection in the workplace, the inspiring principle of the new law is to reinforce workers' protection in the labor market, through a more comprehensive and universal benefit which will replace most of the existing diversified provisions. To this end, the government sought to maintain and extend to all workers the Cassa Integrazione Guadagni (CIG), i.e. the provision supporting workers laid off in the downturn of the cycle. The scheme had previously worked well in situations of temporary lack of demand, but did not cover all workers and had been rather arbitrarily extended over the years, becoming more discretionary and frequently an instrument either to postpone unemployment (CIG for restructuring or "in deroga", i.e. unrelated to previous contributions) or to provide a bridge towards early retirement (the so-called "mobility schemes"). A succession of discretionary provisions could thus keep a worker on such schemes for decades, without any serious attempt to requalify the worker and help him/her find a new job.

A new social protection benefit-called ASpI (Assicurazione Sociale per l'Impiego, i.e. Social Insurance for Employment)-has been introduced, lasting 12 months for workers up to 55 years of age and 18 months from 55 onwards, which considerably extends social protection coverage in terms of both recipients and expenditure. A "mini-ASpI" also covers, at reduced rates, apprentices, short-term workers and young people without much experience in the labor market, who were previously excluded from any social protection provisions, for a period equal to half their working period in the last 12 months.

The reform also established that access to benefits is contingent to the individual's willingness to be active in the labor market (i.e. by participating in re-training courses) or to accept a job offer, at given conditions. In case of refusal-and this is a rather radical departure from the past-the benefit is cancelled. Of course, to be effective these 'stick and carrot" devices need very serious monitoring and implementation, which can be a problem in a country rather unfamiliar with active policies and to contingent benefits.

iv) Fourth pillar

Effective activation policies and quality employment services are indeed a kind of chimera in many Italian regions. The reform included an assignment for future governments a) to lay down principles to redesign ALMP as well as life-long learning provisions; b) to reshape the role of employment services by restructuring their organization, stressing the importance of cost-effectiveness analysis and of increased professionalism in job-centers; c) to realize, possibly within a single agency, a better coordination between passive and active labor market policies.

The government could not, however, accomplish its task because the Regions deemed the government intervention ill-timed, because three of them were scheduled to have elections. Apart from leaving an important part of the reform 
unfinished, this creates a problem of coordination and of uniformity of policies. Indeed, regional governments value subsidiarity very much and are not always ready to give way, in order to realize a national level playing field for workers, so that Southern workers could have access to employment services of the same quality and quantity than those available in the Northern regions.

v) Fifth pillar

The law openly recognizes that reforms are not perfect intellectual products handed down from above into an imperfect world. Rather they resemble fairly rough tools that need regular monitoring, maintenance and adjustment, must be strengthened where they are effective and corrected where they do not work or live up to expectations; they must be tuned to social and economic evolution and also to nonresponsiveness by firms and workers. A permanent flow of data collected from various administrative sources ${ }^{14}$, to be made freely available to the scientific community for independent evaluation of the reform, has been officially started. A monitoring process is under way and the new government has embraced the idea both as the basis for scientific investigation and as the recognition of the principle that changes must be introduced where necessary.

The labor market reform has also provided a chance to tackle the thorny problem of greater inclusion of women in economic and social life, to fight the persistence of discriminatory practices in the workplace and at the level of job protection. Consequently, even within the stringency of tight financial constraints, the reform also introduced specific provisions for women, whose participation to labor market is one of the lowest in Europe (see Additional file 1: Figure S4). These include experimental provisions, trying not only to make working life easier but also to strike a better balance between private life and working life. With the aim of supporting parenthood and of promoting a gender-balanced distribution of childcare within families and of harmonizing the Italian legislation to the European Directives and other countries' provisions a mandatory paternal leave (sadly, very modest) has been introduced consisting of a compulsory day leave in the first three month of the child's life plus two optional days to be shared between parents. Vouchers meant to facilitate mothers' work by easing their access to public and private childcare services have also been introduced. Finally, as already mentioned, a provision trying to prevent the practice of fake resignations, the so-called "dimissioni in bianco", was also included in the law.

\section{Opposition, latent contradictions and political double standards Overcoming ideological barriers and interest blocks}

While rigorous economic analysis provides solid foundations for writing laws, it pays, perhaps understandably, insufficient attention to the social and political dimensions of the problem. Reforms are not usually born in a laboratory, by strictly following theoretical models. In the real world, to get a comprehensive and thorny reform both approved by Parliament and accepted by the population at large is a hard task: an economist turned minister can hardly find comfort in the tools of the trade and stands alone in a strange territory.

Concern for social cohesion and political etiquette require, in Italy as well as in other countries, that any important change involving socio-economic matters in general and 
labor in particular must first be discussed with the social partners, who, in most European countries, play an important, often decisive role in consensus building.

After the swift pension reform had become law, talks with trade unions and employers' associations about the labor market reform started in early January 2012. Two major obstacles soon became evident: lack of agreement among the social partners and the pervasive presence of ideological elements in the discussion, coupled with the fear of losing even small benefits or subsidies. These obstacles were at their highest in the revision of article 18 of the Statute of Workers' Rights and in the redrawing of the map of social protection schemes.

Article 18 had become a banner for workers' rights and for decades unions had insisted that not a word of it must be changed. Three academics-professor Ezio Tarantelli, an economist who had studied under the guidance of Franco Modigliani, and professor Marco Biagi and Massimo D'Antona, two labor law experts-had been shot and killed by terrorists for publicly advocating a profound revision of labor law, including article 18, and for working on technical aspects of the changes. As much as I tried to play down the discussion on article 18, claiming that there were many other important aspects of the labor relationships that warranted careful considerations, public debate always heatedly focused on it. Moreover, unions and employers' associations were completely at odds with each other on this matter.

Somewhat surprisingly, the redrawing of social protection schemes instead found both unions and employers strongly united against change. Both challenged the appropriateness of modifying such an important social institution right in the middle of a depression, without considering, however, that a technocratic government does not choose the time path of its mission and that there had been a precise commitment to change by the previous government. The preference for the status quo-a clear case of a suboptimal equilibrium, highly subsidized by the state, which none of the parties had a real interest in changing-was demonstrated by the fact that a 1997 legislative decree, empowering the government to introduce a reform without further recourse to Parliament had never been acted upon by any government ${ }^{15}$. Irrespective of all the inefficiencies and inequities in the system, it had always been considered that "letting sleeping dogs lie" was the safer course.

In spite of this deeply rooted resistance to change, the first two months of negotiations showed encouraging signs that a satisfactory agreement introducing non-cosmetic changes could be reached. And this was essentially due to external conditions, another factor that economists often tend to overlook when they talk about reforms, but which were crucial in our case.

It was quite clear that European and international institutions supported the government's effort towards reforms and this positively influenced a significant fraction of the population, which could see in the decline of the spread of the Italian sovereign debt against its German equivalent a tangible sign of the country's recovered reputation and financial credibility. Indeed, this almost idyllic situation coincided with a substantial, (although, alas, temporary) improvement in public finances, with public debt auctions showing an unexpectedly high demand and a lowering of interest rates to 2010 levels.

The same favorable financial signs however soon combined with a worsening of the negative trend of the real economy, where production and unemployment were both moving just in the wrong direction, generating negative social and political repercussions 
on labor reform negotiations. The waning of the sense of urgency turned into a growing dissatisfaction with "austerity" in general (and with the pension reform, in particular) and started to erode consensus for the technocratic government and to make the political forces that constituted the majority less sympathetic with our reform efforts.

So while the government received international support, the Italian debate got increasingly stuck on article 18. CGIL, the largest and most conservative of the unions, expressed skepticism and mistrust from the start, maintained an intransigent position throughout the negotiations and ultimately refused to sign the final agreement between the government and the social partners ${ }^{16}$.

CGIL discontent caused growing tensions inside the Democratic Party and led to the government's accepting a modification of the draft of the new article 18, allowing judges to reinstate workers only in the case of "manifest non-existence" of the economic motive as the cause for the dismissal. It so happened that what might appear (and in my opinion is) a relatively small change produced significant negative repercussions: the Democratic Party claimed that a "substantial" modification had been won thanks to the party's political pressure and this caused a sort of "snowball effect". Both the social partners and the political parties started to dissociate themselves from the bill, each of them asking for further changes, to present as victories to their electorate or support group.

In the end, all partners and parties seemed very dissatisfied. Employers were unhappy with what they considered excessive regulation of temporary jobs, insufficient freedom to proceed with individual dismissals and inappropriate changes in social protection schemes ${ }^{17}$. Precisely the opposite criticism came from the trade union side, which branded the reform as too timid in fighting precarious job conditions, too harsh in reducing guarantees against firing and untimely in modifying social protection schemes during a recession. A sense of responsibility, however, prevailed and despite resentful and rhetorical opposition (with declarations of a "never ending battle"), CGIL refrained from calling massive general strikes against the change.

When the reform reached Parliament it not only had very few supporters, but the general climate towards the government had changed ${ }^{18}$. Social and political forces were immediately in action to modify the bill. Again, the international factor came to the rescue: President Monti had to participate in an important meeting of the European Council $^{19}$, which prompted the government to ask for a vote of confidence, allowing the law to be finally approved on June $28 \mathrm{th}^{20}$.

\section{The best possible equilibrium with an eye to European expectations}

In the view of the government, and of the minister of Labor in particular, the reform represented the best possible equilibrium among too conflicting positions. I strongly believe that, if properly applied, the reform will be able to provide the right framework for a more efficient and more equitable functioning of the labor market by rebalancing opportunities in favor of the young, improving productivity and the quality of labor relationships and by reducing market dualism and segmentation. Unfortunately, communication difficulties, implementation problems and absence of immediate results were at the root of widespread criticism and, I must add, of unpleasant personal attacks.

The severity of the recession was one side of the coin. The other, however, was that political parties had already started to think about the coming elections (due in Spring 
$2013^{21}$ ) and wanted not only to distance themselves from the "government of the professors", but to make it a convenient scapegoat for all the long-term inadequacies of the Italian economy. To give just one example, blame for the increase in the unemployment rate was immediately attributed to the reform, much before data could be collected to confirm the claim and regardless of the fact that such reforms require perhaps years and not months to produce effects (as the German experience with the Hartz reforms shows). It so happened that the government came increasingly under attack by the same political forces that had supported it in the first six months of its activity.

\section{Dynamic inconsistencies: short term effects and long term perspectives}

Despite the first encouraging assessments from international institutions ${ }^{22}$, the dynamic inconsistency between unmet short-run expectations (if not of rapid improvement, at least of a stop in labor market deterioration) and better prospects for the medium-long run created a short circuit: the technocratic government was increasingly seen not only as "too theoretical", too prone to abstract austerity per se, but also as responsible for all that was wrong in the Italian economy and society.

When "all the chickens come home to roost", basic cooperation between institutions, social partners, political parties and the media is sorely needed, particularly in soberly presenting the main issues. In the Italian case, however, the electoral campaign created yet another occasion for sharp and vicious clashes among political forces and for distorted presentations to citizens.

In this scenario, the message that reforms need to be endorsed by the various stakeholders was lost. Yet, the ultimate success of a reform rests upon the changes in individual and collective behavior that it can stimulate and support.

A year and a half after the law became operative, are we in a position to claim something more than just the standard rhetoric that "the direction was the right one"?

Apart from the relatively short period, the multiplicity of data sources and their different timing has to be considered. Data on legal procedures concerning illegitimate dismissals, for example, are typically slower to appear than data on hiring and firing, available through compulsory official notifications to the Ministry. As of November 2013, I am not aware of any econometric study assessing the impact of the reform, while three "Monitoring Reports" have been provided by ISFOL (a public research agency, under the supervision of the Ministry), which enable us to examine preliminary evidence of the effects of the reform's first and second pillars, i.e. entrance in and exit from the labor market.

A first observation sadly concerns the sharp contraction of the number of the newly hired (minus 10 per cent in the first quarter of 2013 compared to the first quarter of 2012). The recession hit the Italian economy very hard in 2012 (and in 2013), and this obviously did not help the attempt of the reform to encourage apprenticeship and combat precariousness in the short run.

A different structure of contracts for the newly hired, in tune with the reform, is however clearly visible (ISFOL 2013a). Comparing (with seasonally adjusted data) the second quarter of 2013 with the same quarter of 2012, the share of permanent contracts slightly increased (from 16.8 to 17.5 per cent), as did (very slightly: from 2.6 to 2.8 per cent) that of apprenticeships and (more pronouncedly, from 62 per cent to 67 per cent) that of term contracts. The average length of temporary contracts also 
increased, due to a little gain in term contracts over 12 months, together with a reduction of very short term contracts (2-3 months) (ISFOL 2013b). On the other hand, the share of "project-related jobs" (a kind of temporary contract tied to the realization of a specific project) decreased from 8.2 to 6.7 per cent and that of agency jobs from 8.5 to 4.4 per cent, while a sharp reduction occurred to the so-called "associazioni in partecipazione"23.

The evidence on apprenticeship is rather disappointing: the development of this important contract will require further work and a stronger coordination between schools, firms and employment agencies.

As for exits from the labor market, very preliminary evidence suggests an increase in dismissals and a reduction in resignations: the trends are likely to be interconnected, as a result of the reform's contrast of fake resignations on the one hand and the easier dismissal procedure on the other. Compulsory conciliation procedures have proved to be rather successful, as about 40 per cent of the proposed conciliations in the first 7 months of the reform were agreed upon by the parties. A considerable number of disputes could therefore be settled out of court. The length of legal dismissal procedures has been reduced (Melis 2013).

Regarding "passive" policies, an improvement has occurred in the inclusion of workers in the safety net. In response to the reform, new "solidarity funds", financed by the social partners, have been included in various collective agreements thus extending the traditional CIG to previously excluded workers. The application of ASpI and mini-ASpI reduced the number of employees excluded from all social protection schemes, with coverage including almost all precarious (young) workers, such as apprentices and workers on term contracts. Active policies, however, have made very little progress and cooperation with regional authorities is getting off to a very slow start. A chance for (hopefully rapid) improvement will be provided by the national implementation of the Youth Guarantee.

\section{Conclusion: Alice through the looking glass}

As a final observation, a reflection on the advantages and disadvantages of a technocratic government is appropriate. Such a government has both strengths and weaknesses with respect to a political government. Points of strength include detachment from political squabbles and greater possibility to be super partes, a very appropriate feature when, in a stalled political scene, issues are structural, wide-ranging, highly technical and laden with a high degree of urgency. A technocratic government can make choices for the mediumlong horizon rather than just for the short run, since its ministers are supposed to have a more rigorous base for their choices, to be less-if at all-conditioned by prospective elections, as their own careers do not depend on their popularity with the electorate.

The weaknesses become apparent as soon as any of these points of strength wanes. In particular, when a sense of urgency fades away because "disaster has been avoided" or when, as was the case for Italy, the Prime Minister decides to step into the political arena. Immediately the technocratic government becomes a lame duck: not a single relevant law will be approved by a now restless Parliament. The technocratic government will be judged for its achievements up to that very day; in the case of the Italian experience, these included fundamental reforms that none of the two warring sides would have had the courage to put forward. So it can well be said that the experience was, on the whole, on the positive side but also that its demise was timely. 
Looking back at a 16-month sometimes harrowing government experience, the economist turned technocratic minister feels very much in agreement with Alice in Lewis Carroll's Through the Looking Glass:

"Now, here, you see, it takes all the running you can do, to keep in the same place. If you want to get somewhere else, you must run at least twice as fast as that".

To be effective, i.e. introduce tangible change, with the only comfort of an at best reluctant parliamentary majority, you must go beyond the rules of normal running and somehow manage to run twice as fast.

Change can of course easily be reversed. Ink was not yet dry on the new pension and labor laws when amendments started to be presented which would fundamentally alter the logic of both laws. It is however a source of relief that, as months go by, opposition seems to be abating in society at large: the new mechanisms are providing a more level playing field for younger generations and some grudging recognition is taking the place of passionate negation by those whose positional privileges are being eroded. The idea that a reform is not an external deus ex machina but rather a "living organism" that has to be nurtured and at the same time has to adapt to the outside environment without losing its identity seems to receive some consent. The nation has become (very slightly) wiser and more aware of its difficulties and complexities: we could perhaps say that we left a (slightly) better country than we found.

This may seem overconfident, but I believe that the country made significant steps forward towards the solutions of its structural problems. In pensions, it substantially reduced its implicit pension debt; in labor law is now nearer to European standards. Both changes represent a major rebalancing of opportunities in favor of younger generations. They are to be seen as necessary, but not sufficient conditions. It is encouraging that the present government talks not of overturning the reforms, but of using the "screwdriver" to fix them, working on the monitoring and evaluation procedure of the reform.

Has all this been too harsh a medicine? In hindsight, no: had the message been less clear and credible, the recent "green-light" from Brussels could never have come. This green light is now both a sign of hope for Italian households and a warning to politicians not to revert to bad old habits. With the end of the infraction procedure, our successors' hands are moderately freer. I wish them, and the country, the best success.

As an economist, can the technocratic minister be any wiser? Will her experience alter the curriculum of her courses, the way she teaches, her attitude to research programs? The answer is a succession of "yes, but". Economists have been denouncing imbalances in the pension area for decades and issued stern warnings that went largely unheeded; their approach to the modern labor markets was perhaps less unanimous but policy implications in terms of flexicurity were largely shared; their reluctant disposition to dialogue with other social scientists has produced more harm than good.

It must be restated that economic models are and must remain the core of modern economic thought. They however do not include all the relevant variables. In particular, there is much work to be done in taking into account the influence of interest groups, political parties, bureaucrats, judges and the media, as well as differences in regions, age and skill. This I have learnt the hard way. So I am back in my University with a lot to mull over and a lot of work to do. 


\section{Endnotes}

${ }^{1}$ See The Economist, July 14th, 2011.

${ }^{2}$ This tax (called IMU, Imposta Municipale Unica) was however cancelled by the new government after the February 2013 general elections, in order to fulfill an electoral promise made by the center-right party (the PDL), a member of the old governing coalition.

${ }^{3}$ The most important one is the 1995 reform, which adopted the Defined Contribution method of calculating benefits, allowing however for a very slow phasing in. The new formula was applied entirely only to new entrants, partially (i.e. on a pro-rata mechanism) to workers having less than eighteen years of seniority while elder workers with eighteen or more years of seniority were excluded.

${ }^{4}$ Indeed, seniority pensions as such have been abolished as the system now contemplates, in line with most European systems, only anticipated pensions (with penalization) and old age pensions.

${ }^{5}$ This was later cancelled by the Constitutional Court, who considered the "solidarity contribution" equivalent to an ordinary income tax, ignoring that the defined benefit formulae on which those pensions were calculated implied a very loose connection, at the individual level, between contributions and benefits, and thus realized a regressive redistribution, favoring high income earners. Regrettably, this decision deprived the reform of one of its most noticeable traits of fairness.

${ }^{6}$ The attacks started in particular in connection to the problem of workers already displaced from their job, or in a mobility scheme, in expectation of retiring within a few years, or who had, at some point of their working life, voluntarily left their job expecting pension laws to remain unchanged. The reform established a safeguarding clause for 65,000 workers. It turned out later that the number was largely under-estimated, because many individual and some collective agreements between workers and employers had been concluded without any formal registration. Moreover, public opinion refused to make distinctions inside this group - which the press called "Esodati", referring to a forced exodus from the labor market - and considered all of them as equally deserving to be safeguarded, irrespective of the heterogeneity of their situations. In a couple of subsequent provisions, the government added other 65,000, making a total of 130,000 safeguarded workers.

${ }^{7}$ According to the official projections made by the Ragioneria Generale dello Stato (the Central Government Budget Office, in charge of managing public accounts), the net saving from the pension reform will amount to 80 billion euro in the decade 20122021. See RGS(2012).

${ }^{8}$ See Del Boca and Rota (2008), Brugiavini (2009), Galasso (2010), OECD (2010), OECD (2011). In a country report, the IMF (2011) states: "Policies should reduce labor market dualism. [...]The time-limited nature of temporary contract reduces incentives for human capital investments and temporary employment creation tends to be in lowskill areas. Also, the still high protection of permanent contracts continues to make it difficult to lay off non-productive workers on permanent contracts. [...]. Reforms to rebalance employment protection-with a view to support job creation-by relaxing protection on regular workers while enhancing it for temporary workers would be beneficial for reducing unemployment. Such reforms would create a more level playing-field for all workers and enhance social cohesion". 
${ }^{9}$ See Boeri and Garibaldi (2008) for the Italian case and Lepage-Saucier et al. (2013) for a more recent discussion.

${ }^{10}$ In the case the employer is an innovative start-up this period extends to four years.

${ }^{11} \mathrm{~A}$ subsequent change by the new government has extended this to one year.

${ }^{12}$ The rebate of social contributions is complete for the first three years for firms up to 10 employees and partial (10 per cent instead of 33 per cent) for the others.

${ }^{13}$ In a 2008-09 survey (ISTAT 2011), 13.1 per cent for mothers born after 1973 indicated that their employers 'forced' them to resign upon becoming mothers.

${ }^{14}$ The process involves various institutions such as: the Ministry of Labor, which collects all the data on labor flows; INPS, the pension institute, which has all the administrative data on both workers and retirees; INAIL the institute for insurance against labor accidents.

${ }^{15}$ In 1997, the Prodi government appointed a Commission, chaired by Prof Paolo Onofri, to investigate the overall situation of social protection schemes with a view to a comprehensive reform. In the Final Report (February 28th) the Commission wrote: "The present structure of social protection is a fragmented, incoherent, unmanageable collection of schemes, the result of successive overlapping norms creating unwarranted and pervasive inequities at the expense of the weakest groups in term of political representation".

${ }^{16}$ Lack of understanding may have played a role in determining the trade unions' antagonism. Not being a politician or a trade unionist myself, I failed to realize how much embedded in "rituals" negotiations still were. The trade unions particularly resented my acceptance of an invitation from (more than 1000) workers of a large industrial plant "to discuss with them". They argued that it is not for the Minister to talk directly to workers. Notwithstanding this difficult relationship, I always rejected the idea that an agreement without the most left-wing of the trade unions, the CGIL, would have been preferred by financial markets.

${ }^{17}$ Particularly harsh was the position of Confindustria, notwithstanding the fact that their President had signed the agreement on which the law was subsequently written.

${ }^{18}$ The risk of the reform not being approved or being radically changed was clear to the European Commissioner Laszlò Andor, who, in a parliamentary hearing, declared: "the reform is necessary to increase employment, competitiveness and fairness; the pace of the reform process has to be maintained and responsibility for a rapid approval lies now in the hands of Parliament".

${ }^{19}$ In this meeting (28-29 June, 2012) the European Council adopted the "Compact for growth and jobs".

${ }^{20}$ Law n. 92, June 28th, 2012 "New provisions for the Labor Market within a growth perspective", published in Gazzetta Ufficiale. n.153 July 3rd and effective since July 18th, 2012.

${ }^{21}$ Elections were then brought forward a couple of months, exactly due to the worsening of the political situation and the withdrawal of support to the government by the center right PDL party.

${ }^{22}$ See OECD (2013): “... over the past one-and-a-half years the government has taken a series of measures to enhance the growth potential. These measures have mostly been in line with previous OECD recommendations. They include reforms of the pension system, the tax system, product markets, the labor market, the public administration, and the rule of law." 
${ }^{23} \mathrm{~A}$ leading textile producer provides a significant example: before the reform it employed 1.260 workers, mostly women, as "associati in partecipazione". The reform introduced a ceiling of three "associates" for every firm. Through an agreement with the trade unions, in July 2013 almost all workers were offered a permanent contract, half of them as apprentices.

\title{
Additional file
}

Additional file 1: A statistical comparison of the Italian and European labor markets.

\section{Competing interests}

The IZA Journal of European Labor Studies is committed to the IZA Guiding Principles of Research Integrity. The author declares that she has observed these principles.

\begin{abstract}
Acknowledgements
I thank Klaus Zimmermann for having encouraged me to write this memory; the MEA-Max Planck Institut in Munich for having invited me to visit and provided me with a stimulating environment in which I could start writing; and Axel and Martina Boersch-Supan for having helped me to look at my government experience in a detached way through long, interesting and inspiring discussions. Riccardo Del Punta for reading a first version of the paper; Emilio Rocca for research assistance and Cecilia Brunazzi for proof reading. I also thank Martin Kahanec and participants to the "8th Employment and Development Conference", World Bank \& IZA, Bonn, (August $22^{\text {nd }}-23^{\text {rd }}, 2013$ ) and to the IZA Workshop "Labor Market Reforms during the Great Recession: Challenges and Opportunities" Bruxelles, October 10th for interesting discussions and an anonymous referee for useful suggestions. Above all, I thank my husband, Mario Deaglio, for his patient and persistent moral support during a very difficult, but also exceptional experience. Responsible editor: Klaus F Zimmermann.
\end{abstract}

Received: 4 November 2013 Accepted: 26 November 2013

Published: 16 Dec 2013

\section{References}

Boeri T, Garibaldi P (2008) Un nuovo contratto per tutti. Chiarelettere, Milano

Brugiavini A (2009) Welfare reforms and labour supply in Italy, working paper 2009:29. IFAU-Institute for Labour Market Policy Evaluation, Uppsala

Brummer A (2011) Why Italy is the new Greece. Daily Mail, London. 7 November

Del Boca A, Rota P (2008) Entry and exit flexibility: asymmetries in the Italian labor market. Paper presented at XXII National Conference of Labor Economics, University of Brescia, Brescia. 11-12 September 2008

De Nicola A (2012) Cara Fornero le idee non bastano. Repubblica, Rome. 7 September

Galasso V (2010) Advancing Pensions and Labour-market reforms. In: Making reforms happen: lessons from OECD countries. OECD publishing, Paris

Gammelin C, Bachstein A (2011) Italien-schlimmer als Griechenland. Sueddeutsche Zeitung, Munich. 24 October IMF (2011) Italy: selected issues, Country report no. 11/176, July

ISFOL (2013a) Gli effetti della legge n. 92/2012 sulla dinamica degli avviamenti dei contratti di lavoro. Evidenze ricavate dal Sistema informativo sulle comunicazioni obbligatorie del Ministero del Lavoro e delle Politiche Sociali (dati disponibili al 31 marzo 2013). Available at http://isfoloa.isfol.it/ Accessed 22 Nov 2013

ISFOL (2013b) La dinamica degli avviamenti dei contratti di lavoro anno 2012. Available at http://isfoloa.isfol.it/ Accessed 22 Nov 2013

ISTAT (2011) Maternità e interruzioni dal lavoro. Available at http://www3.istat.it/dati/catalogo/20110523_00/grafici/3_7. html Accessed 22 Nov 2013

Lepage-Saucier N, Schleich J, Wasmer E (2013) Moving Towards a Single Labour Contract: Pros, Cons and Mixed Feelings, OECD Economics Department Working Papers, No. 1026. OECD Publishing, Paris

Melis V (2013) Sul fronte dei licenziamenti oltre 16mila conciliazioni. II Sole 24 ore, Milan. 23 September

OECD (2010) OECD Employment Outlook 2010. OECD Publishing, Paris

OECD (2011) OECD Economic Surveys: Italy 2011. OECD Publishing, Paris

OECD (2013) OECD Economic Surveys: Italy 2013. OECD Publishing, Paris

RGS (2012) Le tendenze di medio-lungo periodo del sistema pensionistico e socio-sanitario, report no.13. Ragioneria Generale dello Stato, Rome

Sacchi S (2013) Italy's Labour Policy and Policy Making in the Crisis: From Distributive Coalitions to the Shadow of Hierarchy. In: The Politics of Social and Industrial Reform. Magara M, Sacchi S (eds.) Edward Elgar, Cheltenham p 195

Tompson W (2009) The political economy of reform. OECD Publishing, Paris

Zimmermann (2013) Imparare dal pragmatico modello tedesco. Aspenia. 2 October

10.1186/2193-9012-2-20

Cite this article as: Fornero: Reforming labor markets: reflections of an economist who (unexpectedly) became the Italian Minister of Labor. IZA Journal of European Labor Studies 2013, 2:20 